\title{
Laparoscopic reduction of ileoileal intussusception in Henoch-Schönlein purpura
}

\author{
Ramnik V Patel, ${ }^{1,2}$ Jigna Sheth, ${ }^{3}$ Hemant Kumar, ${ }^{3}$ Nitin Patwardhan ${ }^{3}$
}

${ }^{1}$ Department of Paediatric Urology, University College London Hospitals NHS Foundation Trust, London, UK ${ }^{2}$ Department of Paediatric Urology, Great Ormond Street Children Hospital NHS Trust, London, UK

${ }^{3}$ Department of Paediatric Surgery, Leicester Royal Infirmary, Leicester, UK

Correspondence to Ramnik V Patel, ramnik@doctors.org.uk
To cite: Patel RV, Sheth J, Kumar $\mathrm{H}$, et al. BMJ Case Rep Published online: [please include Day Month Year] doi:10.1136/bcr-2013200344

\section{DESCRIPTION}

A 4-year-old boy presented with non-blanching palpable skin rash on lower limbs, ankle swelling, cough and sore throat. He had normal blood pressure, enlarged red tonsils with pus and bilateral knee and ankle swellings. Urine dipstick showed $30 \mathrm{mg} / \mathrm{dL}$ of protein and the haematological, biochemical and clotting profile were normal. The patient was diagnosed to have Henoch-Schönlein purpura (HSP). He was discharged home with a leaflet, a prescribed course of amoxicillin and weekly general practitioner follow-up for urine dipstick and blood pressure. He presented again after 5 days with facial and scrotal swelling and was sent home. He was readmitted 4 days later with abdominal pain, vomiting, constipation and abdominal distention of $24 \mathrm{~h}$ duration. Abdomen was distended, soft, non-tender and a mass was felt to the
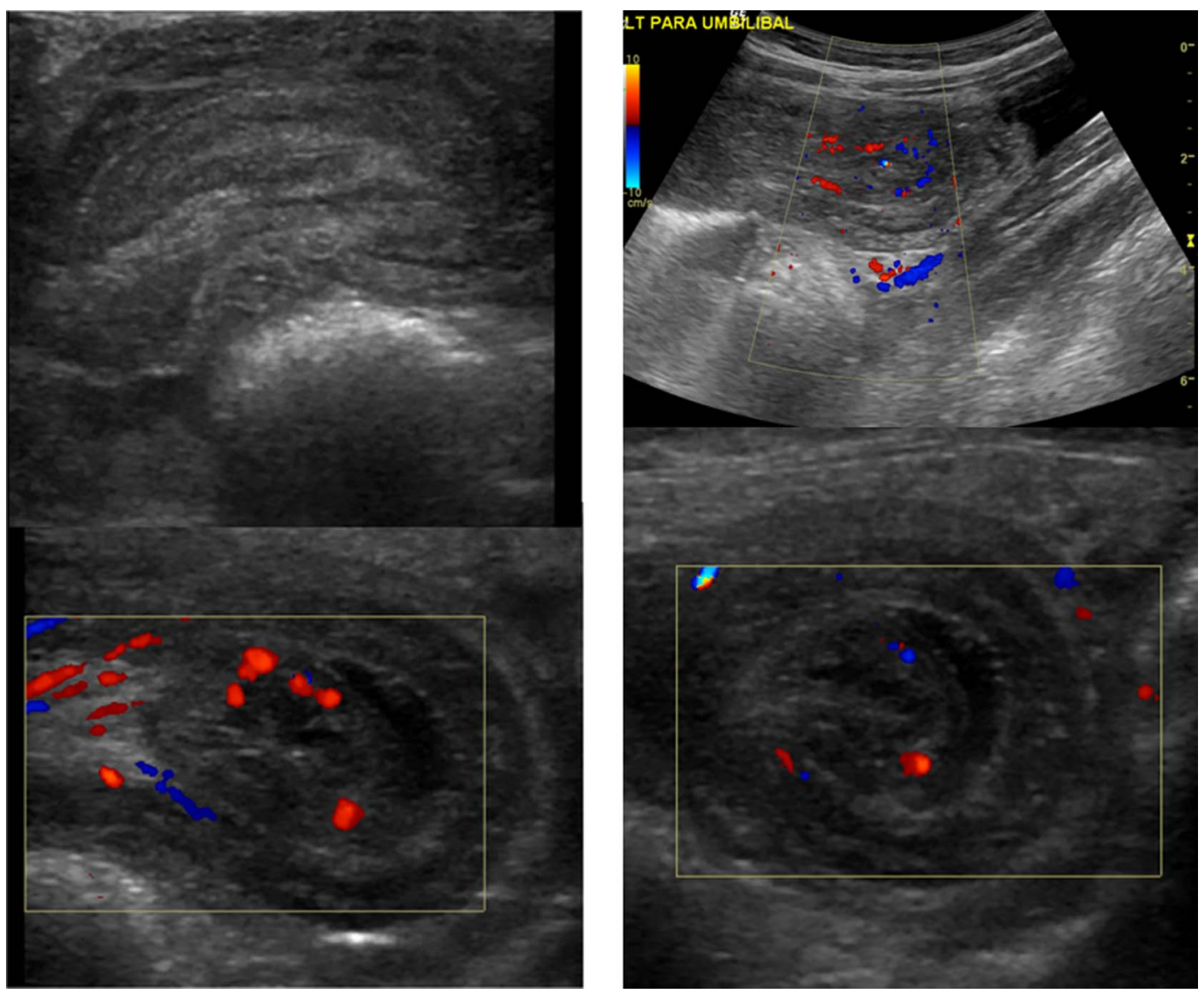

Figure 1 Ultrasound scan and colour Doppler study showing ileoileal intussusception. left of the umbilicus. Ultrasound scan with colour Doppler demonstrated intussusception with doughnut/target and pseudokidney signs together with dilated proximal and collapsed distal small bowel (figure 1). He underwent laparoscopic reduction of ileoileal intussusception uneventfully. Bowel was viable but inflamed, free haemorrhagic fluid was seen in the abdomen. He recovered well and at 2-year follow-up he is well and thriving. Gastrointestinal symptoms in HSP are common but surgical intervention for a rare but serious complication of intussusception is only required in a minority of cases. ${ }^{12}$ A high index of suspicion, imaging studies and laparoscopy are diagnostic and therapeutic. Laparotomy is the traditional approach as air enema reduction is not possible for small bowel lesions in HSP. Laparoscopy is safe, effective, cosmetic, less painful and is recommended. ${ }^{3}$ 


\section{Learning points}

- Intussusception should be considered in the differential diagnosis of all children who present with Henoch-Schönlein purpura (HSP) and abdominal pain.

- Ultrasound and colour Doppler remain the first-line imaging investigation in HSP both in children who present with an abdominal pain, distention, vomiting or mass, and in those in whom intussusception is clinically suspected.

- HSP have small bowel intussusceptions in majority of cases and therefore cannot be reduced with air (or fluid) enema techniques. Laparoscopy is a safe and an effective diagnostic and therapeutic option in this group of patients.
Contributors All authors were actively involved in the clinical management of the patient and have actively participated in the preparation, editing and finalising the manuscript.

\section{Competing interests None.}

Patient consent Obtained.

Provenance and peer review Not commissioned; externally peer reviewed.

\section{REFERENCES}

1 Zmora 0, Shin CE. Multiple surgical interventions due to recurrent intussusception in a patient with Henoch-Schönlein purpura: a case report. Eur J Pediatr Surg 2008;18:340-1.

2 Lai HC. Henoch-Schönlein purpura with intussusception: a case report. Pediatr Neonatol 2010;51:65-7.

3 Burjonrappa SC. Laparoscopic reduction of intussusception: an evolving therapeutic option. JSLS 2007;11:235-7.

Acknowledgements We are very grateful to Dr Peter Houtman, Consultant Paediatrician at Leicester Royal Infirmary, for looking after this patient from medical aspects and referring him to us promptly, and to the paediatric radiology teams and paediatric anaesthetic team involved in this case for their expert services.

Copyright 2013 BMJ Publishing Group. All rights reserved. For permission to reuse any of this content visit http://group.bmj.com/group/rights-licensing/permissions.

BMJ Case Report Fellows may re-use this article for personal use and teaching without any further permission.

Become a Fellow of BMJ Case Reports today and you can:

- Submit as many cases as you like

- Enjoy fast sympathetic peer review and rapid publication of accepted articles

- Access all the published articles

- Re-use any of the published material for personal use and teaching without further permission

For information on Institutional Fellowships contact consortiasales@bmjgroup.com

Visit casereports.bmj.com for more articles like this and to become a Fellow 